\title{
Effect of integrating children's literature and SQRQCQ problem solving learning on elementary school student's mathematical reading comprehension skill
}

\author{
Tita Mulyati ${ }^{a}$, Wahyudin $^{a}$, Tatang Herman ${ }^{a}$ and Tatang Mulyana ${ }^{a}$ \\ a Indonesia University of Education, INDONESIA
}

\begin{abstract}
The aim of this research was to examine the effect of learning application of SQRQCQ problem solving with children's literature toward the reading comprehension skills of elementary school students. This research involved 105 fifth grade students in three intact classes in Bandung. The quasi-experimental research with control class without pre-test was done, but previously prior math knowledge test was conducted to find out the equality of each class ability and grouping them into high, medium, and low. The research data was obtained from test on the prior knowledge in math and written post-test based on two mathematical texts, and each text contain four questions. Data were analyzed using oneway ANOVA and two-way ANOVA. The results from the research show that 1) the learning of SQRQCQ problem solving with children's literature leads to higher effect on the achievement of mathematical reading comprehension skill if compared to both student groups getting other learning, 2) students with high prior math knowledge has higher mathematical reading comprehension skill if compared to two other level of prior knowledge, and 3) there is no interaction effects between the learning done and prior knowledge on the mathematical reading comprehension skill. The research recommended that SQRQCQ problem solving learning with children's literature can be used on mathematics learning in elementary school in order to supporting mathematical reading comprehension skill.
\end{abstract}

KEYWORDS

mathematical reading comprehension, SQRQCQ problem solving learning, children's literature
ARTICLE HISTORY

Received 12 December 2016

Revised 17 May 2017 Accepted 19 May 2017

\section{Introduction}

Problem solving has been the main theme in research and curriculum throughout the world (Torner, Schoenfeld, and Reiss, 2007), including in Indonesia. Indonesia places mathematical problem solving skill as one of the mathematics learning goals and problem solving approaches as the focus on mathematics learning (BSNP, 2006). In the problem solving activity, it is greatly

CORRESPONDENCE Tita Mulyati $\square$ tita@upi.edu

(c) 2016 T. Mulyati et al. Open Access terms of the Creative Commons Attribution 4.0 International License (http://creativecommons.org/licenses/by/4.0/) apply. The license permits unrestricted use, distribution, and reproduction in any medium, on the condition that users give exact credit to the original author(s) and the source, provide a link to the Creative Commons license, and indicate if they made any changes. 
necessary for reading comprehension skill. Based on findings by Orhun (2003), Hite (2009), and Basol, Özel, and Özel (2011), stated that there is a positive correlation between reading skill and mathematical problem solving. The reading accuracy and comprehension held important role in student mathematical thinking process in problem solving activity, so to improve the problem solving skill, it can be done by improving their reading skill.

Morocco, Aguilar, and Bershad (2008) explained that this reading comprehension skill is one of the requirement skills to have multi-literacy supporting the development of the $21^{\text {st }}$ century skills, and the students can obtain in-depth comprehension on a text if they can develop the reading skill strategically, considering on the outline of the texts, thinking critically on texts, and building definitions. But, the mathematics learning by elementary school is lack emphasis on acquisition on reading comprehension skill (Abidin, Mulyati, and Yunansah, 2015), one of the causes in that in 2006 curriculum, mainly in high level classes, it is not demanded on the reading learning implementation (Indonesian language) done integrated with other subjects (mathematics).

From the preliminary study conducted by distributing math problems consisting of narrative questions, questions were added with pictorial, and questions fully using mathematical symbols in a number of elementary schools in Bandung, it is found that most students are having problems in completing the narrative questions which needed the reading skill with comprehension. The students only given the glimpse, so that they did not yet really understand on the issues in the problems. This is corresponding to the research results by Raduan (2010); Pearce, Bruun, Skinner, and Lopez-Mohler (2013); and Phonapichat, Wongwanich, and Sujiva (2014) stated that the student's difficulties in solving math word problem is reading and understanding the problem.

SQRQCQ is one of the problem-solving process learning strategies giving the students ability to gain a holistic understanding through reading activities. SQRQCQ consists of six steps, namely Survey, Question, Read, Question, Compute, and, Question; it was developed by Fay and a variation of Polya's fourstep process and SQ3R. In the SQRQCQ process, the survey was done through quick reading on the problems to comprehend the problem in general; question, ask to determine the questions asked; read, reread the problem to identify linkages between information and facts required to solve the problem; question, ask which operation/ plans/ strategies is going to be used; compute, doing calculations or completed construction; question, ask whether the completed process is correct and the question is answered correctly and the answers are reasonable (Lester and Head, 1999; Kenney, 2005).

However, the research result by Rose (2011) related to the use of SQRQCQ indicates that there is a decrease in the student performance at final assessment, but this is not so significant decrease, this means that the SQRQCQ does not improve the student performance in solving word problems. Nevertheless, the students felt that they can answer the word problem after studying with SQRQCQ, because they read the problems more than once before attempting to solve it and re-read the problems once they solve the problem. It is known, in her research, Rose just taught and trained the SQRQCQ strategy in 
solving the word problems for three times during one week, each of which took as long as more than one hour. That is why, Rose recommended to use the time and practice as much as possible so that can give positive impact on the student performance in solving the word problems.

Based on Rose (2011) research above, it is necessary to take extra time and context to help students comprehend the problem; this can lead the students to have skill to find the necessary suitable information and strategies to solve the problem appropriately. So in this study, it is used children's literature in the form of contextual bigbook and mathematical texts containing any problems related to children's literature. Also, it is necessary to take more time to teach and practice SQRQCQ. This children's literature is math picturebook which is used by presenting the pictures visually to help the students to explain any difficult concepts to understand (Barone, 2011). This is done by combining the words and illustrations in telling a story and being read aloud by the teacher while the students look at the illustration (Reese, 2008). The form of picture book consisting of a combination of text and illustration is a suitable literature for children (Sawyer, 2012).

With that in mind, the purpose of this research is to study the effect of SQRQCQ problem solving learning with children's literature toward the skill of mathematical reading comprehension and comparing it with a four-step problem-solving learning by Polya and usual learning. Beside, because prior knowledge is one of the keys to obtain good comprehension and effective learning (in Tankersley, 2005), then it is studied on the prior math knowledge effects on the mathematical reading comprehension skill in the three lessons. Based on the above, each of the explanatory variables, that is learning models factor and prior knowledge factor predictable give effect on the student's mathematical reading comprehension skill achievement, so the next analysis is to test the effect of the interaction between the learning undertaken and prior knowledge simultaneously on the skill of mathematical reading comprehension, is an additive model or interaction model. If an additive model, the effects of the learning model of the mathematical reading comprehension skill is the same for all three levels of prior knowledge, or the prior knowledge effect of mathematical reading comprehension skill is the same for all three learning models, and vice versa on the interaction model.

\section{Method}

There are 105 students of $5^{\text {th }}$ grade elementary school involved in this research. They are divided into 3 classes ( $1^{\text {st }}$ experiment, $2^{\text {nd }}$ experiment and control). Beforehand, there is a test on prior math knowledge for the three classes to know the homogenous of student ability. Also, students in each class are divided based on their prior math knowledge, into students in high, medium and low groups. The $1^{\text {st }}$ experimental class obtains SQRQCQ learning problem solving with children's literature, the $2^{\text {nd }}$ experimental class obtains problemsolving learning of Polya's four-step, and the control class obtains usual learning. In the $1^{\text {st }}$ experimental class, the learning activity starts with listening to stories and illustrations in children's literature read by the teacher, reading mathematical text related to children's literature and containing the problem, solving the problem in text by using SQRQCQ step. Children's literature being used such big book $(60 \mathrm{~cm} \times 50 \mathrm{~cm}, 35$ pages $)$. In the $2^{\text {nd }}$ experiment class, the 
learning starts by giving problems, then solve the problems with Polya's four steps. In the control class, the learning is done as usual.

At the end, $1^{\text {st }}$ experiment class, $2^{\text {nd }}$ experiment, and control classes participate on the mathematical post-test reading comprehension skill to determine whether there is a significant difference between the mean value of the three groups after getting on different learning process. The post-test contains two mathematical texts, each of which contains 4 questions measuring on reading comprehension indicators, among others are: recognize/ interpret information in the text, evaluate statements related to the text, and gave new ideas on the questions related to the text. The post-test obtains reliability coefficient of 0.86 , this shows a high level of reliability. The students' answer are tested based on the scoring rubric set up. The total score obtained if the students answer correctly is 18 , then converted to a scale of 100 . After that, the data is analyzed using mean value, standard deviation, and two-way ANOVA with 5\% significance level.

\section{Findings}

The effects of SQRQCQ problem solving learning with children's literature was analyzed by comparing the mathematical reading comprehension skill of three research classes. But, the difference mean was tested on the prior math knowledge score. The description data of prior math knowledge and students' mathematical reading comprehension skill can be seen in Table 1.

Table 1. Decription Data on Prior Math Knowledge and Post-test on Mathematical Reading Comprehension Skill

\begin{tabular}{|c|c|c|c|c|c|c|c|}
\hline \multirow{2}{*}{ Category } & & \multicolumn{3}{|c|}{ Prior Math Knowledge Data } & \multicolumn{3}{|c|}{$\begin{array}{l}\text { Post-test of Mathematical } \\
\text { Reading Comprehension } \\
\text { Skill Data }\end{array}$} \\
\hline & & $\mathrm{N}$ & Mean & $\begin{array}{c}\text { Standar } \\
\text { Deviation }\end{array}$ & $\mathrm{N}$ & Mean & $\begin{array}{c}\text { Standar } \\
\text { Deviation }\end{array}$ \\
\hline \multirow{3}{*}{$\begin{array}{l}\text { Learning } \\
\text { Model }\end{array}$} & 1st Experiment & 37 & 59.12 & 13.22 & 37 & 55.77 & 15.34 \\
\hline & 2nd Experiment & 32 & 60.73 & 15.32 & 32 & 43.54 & 16.51 \\
\hline & Control & 36 & 62.44 & 12.08 & 36 & 36.806 & 12.17 \\
\hline \multirow{3}{*}{$\begin{array}{l}\text { Prior Math } \\
\text { Knowledge } \\
\text { Level }\end{array}$} & High & & & & 25 & 60,93 & 15.05 \\
\hline & Medium & & & & 51 & 45.52 & 12.60 \\
\hline & Low & & & & 29 & 32.30 & 9.54 \\
\hline
\end{tabular}

In Table 1, it can be seen the data of students' prior math knowledge in the three groups of learning models and the data of reading comprehension skill in the category of learning models and the level of prior math knowledge. The test result of students' prior math knowledge in the three groups of learning model shows no much differences, nevertheless statistical test must be 
implemented to see whether there is such difference by using the one way anova. The post-test results of students' mathematical reading comprehension skill in three groups of learning model and prior math knowledge level show differences, but it should be tested whether there is any difference in the effect using twoway ANOVA. Previously, it is conducted data normality test using Shapiro-Wilk test and data homogenity test using Levene test as a prerequisite for testing on these differences.

Table 2 Results on Normality Test and Homogenity Data of Prior Math Knowledge and Post-Test on Mathematical Reading Comprehension Skill

\begin{tabular}{|c|c|c|c|c|c|c|c|c|}
\hline \multirow{2}{*}{ Data } & & \multicolumn{3}{|c|}{ Shapiro-Wilk } & \multicolumn{4}{|c|}{ Levene } \\
\hline & & Statistic & $\mathrm{df}$ & Sig. & Statistic & $\mathrm{df}_{1}$ & $\mathrm{df}_{2}$ & Sig. \\
\hline \multirow{3}{*}{$\begin{array}{l}\text { Prior Math } \\
\text { Knowledge }\end{array}$} & 1st Experiment & 0.94 & 37 & 0.06 & \multirow{3}{*}{1.20} & \multirow{3}{*}{2} & \multirow{3}{*}{102} & \multirow{3}{*}{0.31} \\
\hline & 2nd Experiment & 0.97 & 32 & 0.37 & & & & \\
\hline & Control & 0.97 & 36 & 0.50 & & & & \\
\hline \multirow{6}{*}{$\begin{array}{l}\text { Post-test of } \\
\text { Mathematical } \\
\text { Reading } \\
\text { Comprehension } \\
\text { Skill }\end{array}$} & 1st Experiment & 0.96 & 37 & 0.21 & \multirow{3}{*}{0.97} & \multirow{3}{*}{2} & \multirow{3}{*}{102} & \multirow{3}{*}{0.38} \\
\hline & 2nd Experiment & 0.96 & 32 & 0.31 & & & & \\
\hline & Control & 0.97 & 36 & 0.41 & & & & \\
\hline & High & 0.95 & 25 & 0.25 & \multirow{3}{*}{2.98} & \multirow{3}{*}{2} & \multirow{3}{*}{102} & \multirow{3}{*}{0.06} \\
\hline & Medium & 0.99 & 51 & 0.82 & & & & \\
\hline & Low & 0.98 & 29 & 0.69 & & & & \\
\hline
\end{tabular}

From the Table 2, all results of normality tests gave Sig. Value of $>0,05$; so, all data is distributed normally. Also in the homogenity test results, all gave Sig. Value of $>0,05$ showing that the data has similar variances. The results of mean difference testing on students' prior math knowledge in the three groups before getting on the learning using one-way ANOVA can be seen in Table 3.

Table 3 Test Results on Prior Math Knowledge Difference

\begin{tabular}{lrrrrr}
\hline & Sum of Squares & df & Mean Square & F & Sig. \\
\hline Between Groups & 202.77 & 2 & 101.39 & 0.55 & 0.58 \\
Within Groups & 18679.36 & 102 & 183.13 & & \\
Total & 18882.13 & 104 & & & \\
\hline
\end{tabular}

From Table 3, the overall students' prior mathematics knowledge in the three groups of learning models is obtained the value of $\mathrm{F}=0.55$ and the Sig. 
value of 0.58 . Because the Sig. value is more than 0,05 ; then there is no difference of the prior math knowledge among the three groups before getting on the learning process. It shows that the students' prior knowledge in three learning groups are similar.

Analysis to show whether there is a difference between the students' mathematical reading comprehension skill can be viewed from the effect of different learning models and prior knowledge, it is used two-way ANOVA on the data of students' mathematical reading comprehension skill of all students in the $1^{\text {st }}$ experiment, $2^{\text {nd }}$ experiment, and control class. The results of the calculation are presented in Table 4.

Table 4 Tests of Between - Subjects Effects

Dependent Variable: Reading Comprehension Skill

\begin{tabular}{lrrrrrr}
\multicolumn{1}{c}{ Source } & Sum of Squares & df & $\begin{array}{c}\text { Mean } \\
\text { Square }\end{array}$ & F & Sig. & $\boldsymbol{\eta}_{G}^{2}$ \\
\hline Corrected Model & $19300.83^{\mathrm{a}}$ & 8 & 2412.60 & 30.36 & 0.00 & \\
Learning & 7474.49 & 2 & 3737.24 & 47.02 & 0.00 & 0.52 \\
Prior Knowledge & 12019.55 & 2 & 6009.77 & 75.62 & 0.00 & 0.63 \\
$\begin{array}{l}\text { Learning * Prior } \\
\text { Knowledge }\end{array}$ & 478.62 & 4 & 119.66 & 1.51 & 0.21 & 0.06 \\
Error & 7629.60 & 96 & 79.48 & & & \\
Corrected Total & 26930.43 & 104 & & & & \\
\hline
\end{tabular}

a. $\mathrm{R}$ Squared $=0,72($ Adjusted $\mathrm{R}$ Squared $=0,69)$

In Table 4 based on calculation results of two-way ANOVA, it is obtained the adjusted $R$ square coefficient of 0.69 . It means that the variables of learning and variable of prior knowledge are predicted to be able to affect on students' mathematical reading comprehension until 69\%; meanwhile the remaining of $31 \%$ is affected by other variables beyond this research. The effect of interaction between learning and prior knowledge is additive model or there is no interaction, because from the source derived from learning*prior knowledge, it is obtained the $\mathrm{F}$ value of 1.51 with the sig. value of $0.21(<0.05)$, so there is no interaction effect between learning model done and prior knowledge level simultaneously against the achievement of mathematical reading comprehension skill. This result is in line with the value of generalized eta square $\left(\eta_{G}^{2}\right)$, namely by 0.06 ; meaning that the number of square between the learning model and prior knowledge only represents by $6 \%$ out of the variability total value of mathematical reading comprehension skill. Based on the criteria of effect size from Cohen (in Bakeman, 2005), so the interaction between learning and prior knowledge has small effect size because it is obtained $\eta_{G}^{2}$ less than 0.13 . 
From both results, it can be concluded that simultaneously, learning and prior knowledge factors do not differ the students' mathematical reading comprehension skill. The effect of learning model factor on the mathematical reading comprehension skill does not depend on prior knowledge factor, and the other way around. This causes two main effects, namely learning factor and prior knowledge factor, to be meaningful in affecting on the achievement of students' mathematical reading comprehension skill, so that the test of effect for learning factor and prior knowledge can be done.

From Table 4 for the main effect of learning factor, it is obtained the value of $\eta_{G}^{2}$ by 0.52 . From the value, it can be said that the number of square from the learning model factor represents by $52 \%$ out of value variability total of mathematical reading comprehension skill. This value of $\eta_{G}^{2}=0,52$ shows the large effect size, because it is more than 0.26 (in Bakeman, 2005). In addition, for this learning model factor, it is obtained the F value of 47.02 with Sig $=0.00$ $(<0.05)$ meaning that there is different mean of mathematical reading comprehension skill between students learning by SQRQCQ problem solving learning with children literature, Polya four problem solving process learning and usual learning. This means that out of there three learning models, there are different effects on the mathematical reading comprehension skill with other models with significance level of $5 \%$. Because there is different effect of learning model factor on the mathematical reading comprehension skill significantly, so it is done further test by scheffe, that can be seen in Table 5 as follow.

Table 5 Multiple Comparisons

\begin{tabular}{rlrr}
\hline (I) Learning & (J) Learning & Mean Difference (I-J) & \multicolumn{1}{c}{ Sig. } \\
\hline \multirow{2}{*}{$1^{\text {st }}$ Experiment } & $2^{\text {nd }}$ Experiment & $12.23^{*}$ & 0.00 \\
& Control & $18.95^{*}$ & 0.00 \\
\hline \multirow{2}{*}{$2^{\text {nd }}$ Experiment } & $2^{\text {nd }}$ Experiment & $-12.23^{*}$ & 0.00 \\
& Control & $6.73^{*}$ & 0.01 \\
\hline \multirow{2}{*}{ Control } & $1^{\text {st }}$ Experiment & $-18.95^{*}$ & 0.00 \\
& $2^{\text {nd }}$ Experiment & $-6.73^{*}$ & 0.01 \\
\hline
\end{tabular}

*. The mean difference is significant at the .05 level.

From Table 5, from the mean difference, it can be seen that the $1^{\text {st }}$ experiment group has the highest mean of mathematical reading comprehension skill than two other groups, and the $2^{\text {nd }}$ experiment group has higher mean of mathematical reading comprehension skill than control group. It can be concluded that students with each learning show significance difference in case if mean of mathematical reading comprehension skill, and from the analysis results of prior knowledge test, it is known that there is no mean different of prior knowledge values between three student groups before getting SQRQCQ problem solving learning with children literature, Polya four problem solving 
process and usual learning or it can be said that the three student groups has equal prior knowledge. Therefore, out of the three learning models, SQRQCQ problem solving process with children literature has the highest effect on the mathematical reading comprehension skill than two other models and it is suspected that it is the most appropriate model to be implemented in the achievement of mathematical reading comprehension skill.

Another main factor affecting on the mathematic reading comprehension skill is prior knowledge. Still from the two-way ANOVA results in Table 4, it can be seen that the value of generalized eta square for prior knowledge factor is 0.63 . This value shows that the prior knowledge factor has large effect size, because it is obtained $\eta_{G}^{2}$ more than 0.14 (in Lenhard and Lenhard, 2016) and it can be said that if the number of square from prior knowledge factor represents $63 \%$ out of the value variability total of reading comprehension skill. The value of $\mathrm{F}=75.62$ with $\mathrm{Sig}=0.00(<0.05)$, means that there is different mean of mathematical reading comprehension skill between students with high, medium, and low prior knowledge getting SQRQCQ problem solving learning with children literature, Polya four problem solving process, and usual learning. It means that out of the three prior knowledge groups, in the significance level of $5 \%$, there is different effect on the mathematical reading comprehension skill with other prior knowledge. It is done further test with scheffe to see the different effect of prior knowledge factor on the mathematical reading comprehension skill, that can be seen in Table 6 as follow.

Table 6 Multiple Comparisons

\begin{tabular}{llrr}
\hline (I) Prior Knowledge & (J) Prior Knowledge & Mean Difference (I-J) & \multicolumn{2}{c}{ Sig. } \\
\hline \multirow{2}{*}{ High } & Medium & $15.41^{*}$ & 0.00 \\
& Low & $28.64^{*}$ & 0.00 \\
\hline \multirow{2}{*}{ Medium } & High & $-15.41^{*}$ & 0.00 \\
& Low & $13.23^{*}$ & 0.00 \\
\hline \multirow{2}{*}{ Low } & High & $-28.64^{*}$ & 0.00 \\
& Medium & $-13.23^{*}$ & 0.00 \\
\hline
\end{tabular}

*. The mean difference is significant at the .05 level.

From Table 6, it can be seen that high group students has the highest mean of mathematical reading comprehension skill than two other groups, and medium group has higher mean of mathematical reading comprehension skill than the low group. It can be concluded that there is different mean of mathematical reading comprehension skill between students with each prior knowledge. Therefore, out of the three prior knowledge groups, the students with high prior knowledge has higher achievement of mathematical reading comprehension skill than the students in other two group.. 


\section{Conclusion and Discussion}

The reading comprehension skill is one part of the literacy skills. The results of PIRLS (Progress in International Reading Literacy Study) in 2011 and PISA (Programme for International Student Assessment) in 2012, revealed that there is a low ability of some Indonesian students in reading literacy. This low literacy reading is also occured in mathematical literacy. Mathematical literacy is the ability to explore, suspect, and reason logically, and use different mathematical methods effectively to solve any problems (Wahyudin, 2008) involving high-level of thinking skills. Thus, it can be said that the mathematical reading comprehension skill includes as a difficult one for students.

Overall, the mean value for the mathematical reading comprehension skill for the students in the $1^{\text {st }}$ experiment group, $2^{\text {nd }}$ experiment, and control is respectively 55.77; 43.54; and 36.81. After a test with two-way ANOVA, it shows that the learning model factor has a strong effect size to the achievement of mathematical reading comprehension skill, it is also found differences in the reading comprehension skill caused by different learning process taken. Based on the post-hoc test results with Scheffe test, it is found that among students going through each learning process shows significant difference in the mathematical reading comprehension skill.

The $1^{\text {st }}$ experiment group has the highest reading mathematical comprehension skill than two other groups. From the analysis result of prior math knowledge, it is known that going through different learning process, there is no difference in the mean value of prior math knowledge in all three student groups. So, it can be concluded that the learning process by the $1^{\text {st }}$ experiment group is more appropriate to be applied because it gives more effects on the achievement of mathematical reading comprehension skill. This may be caused by the test of reading comprehension skill given contains mathematical text. They should read the text to be able to solve the problems based on the written story content in the mathematical text. The students in the $1^{\text {st }}$ experiment group are estimated to be more used in reading mathematical text than the students in two other groups, because during the learning process, the students are always faced to reading activity on the text before solving the problems by implementing the SQRQCQ steps.

The reading text activity done by the $1^{\text {st }}$ experiment group on the learning process is conducted every odd meeting; it is after the activities of listening to story, listening to illustration, and understanding on mathematical concepts in children's literature read by the teacher in front of class. The mathematical text to be read these students are in the students' worksheets. The text contains corresponding contexts to children's literature and problems to be solved by the students' by using SQRQCQ problem-solving steps as written in the worksheet. In the reading text activity, the students are asked to try to understand the text content, they are also directed to mark any important information to be used to help to solve problems. This is done so that the student can distinguish between any important information and unimportant one. In addition, the students are also asked to think to understand/ interpret the texts.

Figure 1 presents an example of interrelated children's literature and mathematical text. In children's literature pages 19-21 tells about the three 
main characters, namely Didi, Imas, and Elis were picking cherry fruit in the field and each got as much as half a can. They try to understand if two half cans of cherry fruit is the same with a full can of cherry fruit, so the number of cherry fruit that they all get put together is one and a half cans. The story continues in mathematical text 4 with the title "Pintarnya Kakak Didi" which tells Didi experience after returning home who are confused about how the rest of his cherry fruit if eaten by a third. Fortunately, his brother helped so that Didi can solve the problem.

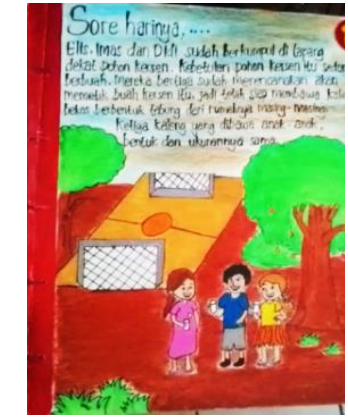

Page 19

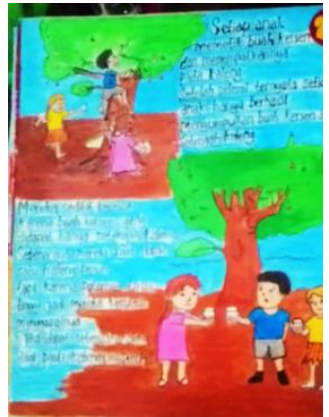

Page 20

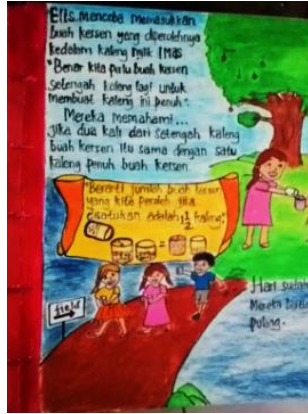

Page 21

\section{PINTARNYA KAKAK DIDI}

Saat pulang ke rumah, Didi langsung ke dapur untuk mencuci $\frac{1}{2}$ gelas buah kersen miliknya. Setelah dicuci, ia memakan $\frac{1}{3}$ bagiannya. Setelah itu, Didi pun mandi. Saat mandi, Didi berpikir, "buah kersen sudah dimakan $\frac{1}{3}$ bagiannya, jadi berapa bagian gelas yang sudah saya makan?" Didi terus berpikir, sampai ia tidak sadar sudah selesai mandi.

Didi masih penasaran, akhirnya ia bertanya pada kakaknya. Kakak Didi mengatakan bahwa kersen yang sudah Didi makan adalah $\frac{1}{6}$ bagian. Tinggal dikali saja, $\frac{1}{2}$ dengan $\frac{1}{3}$ atau ditulis $\frac{1}{2} \times \frac{1}{3}=\frac{1}{6}$. Tapi Didi keliahatannya belum paham. Akhirnya, kakak membawa dua buah gelas dan sebungkus gula. Salah satu gelas diisi penuh dengan gula. Gelas yang lain dibiarkan kosong. Kemudian kakak menumpahkan $\frac{1}{2}$ gelas gula itu pada gelas yang kosong. Jadi masing-masing gelas berisi $\frac{1}{2}$ gelas gula. Kakak mengambil salah satu gelas dan menunjukkan pada Didi. "Kamu sudah makan $\frac{1}{3}$ nya, berarti sisanya tinggal $\frac{2}{3}$. Jika setiap makan, kamu menghabiskan $\frac{1}{3}$ bagian, berarti $\frac{1}{2}$ gelas buah kersen ini akan habis dalam 3 kali makan, dan kalau 1 gelas penuh berarti 6 kali. Jadi, kalau kamu 
makan $\frac{1}{3}$ dari $\frac{1}{2}$ gelas, maka kamu sudah memakan $\frac{1}{6}$ nya”. Didi pun akhirnya paham.

Kakak ingin mengetes Didi, kakak memberi pertanyaan "berapa $1 \frac{1}{2}$ dari 2 $\frac{1}{2}$ ?" Didi kebingungan menjawabnya. Coba bantu Didi untuk menjawab pertanyaan kakaknya.

Figure 1 An Example of Children's Literature and Mathematical Text

Children's literature and mathematical text has the same role in learning, although different in student's activities. Both of these learning resources are used to build the skill of reading comprehension mathematical students. This skill can develop optimally with the help of context that encourages students to use the skill of understanding and thinking in problem-solving activities such as reading, identifying key information and issues, determine the relationship between information, exploring strategies of problem solving, perform calculations based on the strategy that have been, and to check the right of the process and results of the calculation.

In the early days of learning, it is very hard to get students to understand the texts, the students just read them, without marking on any important information and it seems that they are not trying to understand the texts, because when they are asked about the text content, what the problems are, how to resolve the problems, there are no students giving correct answers. The answers given are simply by mentioning the title of text and any words showing their incomprehension, such as 'being confused', 'have no ideas' and so on. There are also many students refusing to reread the dtext when they are ask to do so, because for them, they have read it. Therefore, the students are always given understanding, that if they still cannot mention about the story content, the problems to be resolved, any important useful information to solve the problems, these mean that they still do not understand the text, it also means that they do not read yet, so it is necessary for them to reread.

It seems that students are still not motivated to read, although all students at each meeting are always very enthusiastic, showing a sense of interest and curiosity when the teacher reads the children's literature. This is corresponding to the interview results with some students related their opinion on starting the learning process by reading story books, all of the students say that they enjoy it. Even during the learning process, for the first time teacher shows the children's literature, the students give their great curiosity. They give many questions, among others are: "what is it, ma'am?", "what is it about, story book or picture book?", "did you buy it or make it by yourself, ma'am?" "what is made of?" and others. However, the interview results on how to understand the problems in the texts quickly showing any students saying "I have read it, but it is difficult". In fact, there is a male student saying, "Ma'am, it's difficult, just give multiplication for math, do not read any texts". In this case, it seems that the students feel comfortable and accustomed to learning directly by presenting math simbols.

Then, the text reading activity gets good development. At first, there are many groups only reading without marking on any important information. 
Then, almost all groups mark on the important information in the text by using a pencil or high lighter. However, it seems there are some students giving marks on the entire text contents. This may be caused by the student inability to distinguish between important and unimportant information. The teachers advise to mark only on the important information. Thus, then the students can mark on the important in the following learning process. In addition, sometimes the students are delighted when they are managed to select any important information and successfully solve the problems in the text. Nevertheless, until the end of the study, there are still some students showing no interest in reading. However, at least the students are taught to read. This is understandable because it is not easily to change habit (Wood and Neal, 2007) and the duration for a person to be able to establish new habits depends on each individual (Lally, van Jaarsveld, Potts, and Wardle, 2010).

The habit of reading is crucial to be invested and developed by students. The use of language in mathematics learning is a communication tool and carrier of knowledge. These lead to the reading skill as a serious problem in the discussion and research. As research conducted by Imam Abas-Mastura, and Jamil (2013); Vilenius-Tuohimaa, Aunola, and Nurmi (2008); and Ozsoy, Kuruyer, and Cakiroglu (2015) stated that a person with lower language skill correlates to poor ability in mathematics. In addition, the importance of mastering reading skill is indicated also in the PISA study with the assessment focus on the reading domain conducted in 2000 and 2009 (Funke, 2013).

In addition to the factor of learning models, in this study, it is also analyzed the achievement of mathematical reading comprehension skill based on the level of prior knowledge by the students. This prior knowledge is specific to each subject matter (Roschelle, 1995) and in mathematics, according to Sxhiefe and Csikszentmihalyi (in Murray, 2013), the prior knowledge greatly affects on the students' mathematical ability. Therefore, naturally, students with high mathematical prior knowledge will be more quickly in receiving any concept and procedural taught, adjusting to lessons, and obtaining higher performance. However, the result is not only the same, such as in a research by Ismaimuza (2011), it is said that the problem-based learning with cognitive conflict strategy affects greatly on the students with low mathematical prior knowledge, so it is suitable for students with low prior knowledge.

This may be caused by students' characteristics or the learning process undertaken. First, seen from the students' characteristics, in one class, most students are in medium category, some students in high category, and several other in low category. If the learning is too fast, the students with low ability will be left behind; on the contrary, if it is too slow, the students with highability will be bored (Lie, 2002) because they think that they are able for that, and so forth. Second, from the learning characteristics, the appropriate learning is adapted to the level of students' progress. Elementary students are at the stage of concrete operations, generally children at this stage have understood the logical operation using any concrete objects. The use of concrete objects can be stopped if the pictorial representation can already be represented or understood the students, and the pictorial representation can be stopped when the symbol representation has been understood by the students. When the teachers still using concrete objects or pictorial representations, the students 
with high ability may not need it anymore and feel bored, so that the learning is more suitable for students with medium or low ability.

In this study, an analysis on the achievement of mathematical reading comprehension skill based on the students' prior knowledge is done because of the learning characteristics undertaken, namely the $1^{\text {st }}$ experiment group starting the activity by listening to children's literature is considered as the appropriate one and acceptable to all groups of students' prior knowledge level; the context of mathematical text related to children's literature enables the students to see any correlation between mathematical concepts and everyday life, as well as the SQRQCQ steps enable the students to solve problems systematically. In the $2^{\text {nd }}$ experiment group, it starts by giving problem to be solved with the four step problem solving by Polya, and the control group conducts the usual learning. From the analysis, it is found that the prior knowledge gives a strong effect size and there is difference in the students' mathematical reading comprehension skill as a result of different prior math knowledge.

There is also difference in reading comprehension skill in each group of prior knowledge. There is higher students' reading comprehension skill in the group with high prior math knowledge compared to other two groups. The conclusion is out of the three group of prior knowledge, student with high prior knowledge has higher achievement of mathematical reading comprehension skill than other two of prior knowledge. In other words, the learning process done is more beneficial for students with high-level of prior math knowledge.

This may be caused by the students with high prior math knowledge are more quickly to understand the important information, the question asked, and the relationship between the important information involving mathematical knowledge they already had, making them easier to solve the problems. When students correlates between the prior knowledge and reading the text, then this will lead to the increasing of their understanding on the text (in https://www.teachervision.com). It is also mentioned that there is a large number of research on the prior knowledge are focused on the improvement of reading comprehension skill, and the prior knowledge is necessary for students to read in order to learn a variety of subjects (Campbell and Campbell, 2009).

In this study, the reading comprehension activity is accustomed during the worksheet process activities, at the survey and read stage. In the survey stage, the students are asked to read the text quickly and write information known in the text to be used to help to solve problems. And at the read stage, the students are asked to reread the text carefully, then write down the link between information known to help to solve the problems. From the observation result, it seems that the students with high prior knowledge are more quickly to fill in based on the commands on these two steps. In contrary, it is different to the students with low prior knowledge, the students with high prior knowledge look more persistent and confident, they give more efforts to read and reread to interpret the readings and fill in the worksheet process activity, their curiosity encourages them to take risks in resolving problems.

In the these three learning groups, the students with low prior knowledge results in lower results, although particularly in the $1^{\text {st }}$ experiment group, the lesson begins with the use of children's literature as a context to facilitate 
students to understand the concepts and solve problems. This literature is used referring to the learning theory by Dienes saying that there are some children enjoying mathematics only at the beginning part, one of the causes is that at the beginning part, it is widely used contexts (Simanjuntak, 1992). From the results obtained, it seems that the children's literature is not only required by students with low prior knowledge, but, the students with high prior knowledge are also required it.

Despite that, from the calculation and data analysis, it can be concluded that there is no interaction effect between the implemented learning process and the students' prior knowledge simultaneously on the students' mathematical reading comprehension skill. It is also obtained small effect size. This means that the effect of learning model factor on the reading comprehension skill does not depend on the level of students' prior knowledge or that there is similar effects of learning process on the reading comprehension skill in each group of prior knowledge. So, the learning process done is relatively suitable for all groups of prior knowledge on the students' mathematical reading comprehension skill. This results in a main effect, the learning factor and the prior knowledge factor are meaningful in the achievement of mathematical reading comprehension skill.

There is also significant mean difference of mathematical reading comprehension skill between the students with each learning process. This shows that the students in the $1^{\text {st }}$ experiment group has higher reading comprehension skill than other two groups. This shows that there is higher effects of the problem solving learning of SQRQCQ with children's literature on the reading comprehension skill than other two learning models, because from the data analysis on the mean value of prior knowledge, there is no differences of prior math knowledge between the three groups of students before going through different learning models. Related to the prior knowledge factor, the differences in the students' mathematical reading comprehension skill among students in each group of prior knowledge show that at all levels of prior knowledge, the students with high prior knowledge obtain higher scores in the achievement of skill compared to two other student groups. This shows that high prior knowledge leads to more effects, so it is still necessary for the students with low prior math knowledge to develop curiosity, perseverance, and selfconfidence. It is said that it is definitely difficult to change habit, but it can be done by a strong commitment (Covey, 2008).

From the test results related to the mathematical reading comprehension skill, it can be concluded that the SQRQCQ problem solving learning with children's literature can encourage students to read text containing problems, mark on any important information, think to interpret the reading content by involving their knowledge in the organization and adaptation processes, and writing on the problem solving bythe problem solving steps. Such learning process is in line with the Piaget's constructivist learning concept. In this learning model, the students utilize their thinking skill to recognize and interpret the reading content, evaluate statements related to the texts, and presenting new ideas related to the texts.

According to finding of this research, it was recommended that children's literature supporting the SQRQCQ problem solving learning can be used in 
elementary school. As a result, this quasi-experimental research can promote researchers for further to examine the effectiveness of using this learning model on developing students' habit to read with comprehension and solving of mathematical word problem.

\section{Disclosure statement}

No potential conflict of interest was reported by the authors.

\section{Notes on contributors}

Tita Mulyati - Indonesia University of Education, Indonesia

Wahyudin - Indonesia University of Education, Indonesia

Tatang Herman - Indonesia University of Education, Indonesia

Tatang Mulyana - Indonesia University of Education, Indonesia

\section{References}

Abidin, Y., Mulyati, T., dan Yunansah, H. (2015). Pembelajaran literasi dalam konteks pendidikan multiliterasi, integratif, dan berdiferensiasi. Bandung: Rizqi Press.

Badan Standardisasi Nasional Pendidikan (BSNP) (2006). Pedoman penyusunan kurikulum tingkat satuan pendidikan. Jakarta: Depdiknas.

Bakeman, R. (2005). Recommended efect size statistics for repeated measures designs. Behaviour Research Methods, 37 (3), 379-384.

Barone, D. M. (2011). Children's literature in the classroom: Engaging lifelong readers. New York, NY: Guilford Press.

Basol, B., Ozel, S., dan Ozel, Z.E.Y. (2011). "The relationship between reading comprehension competence and word problem comprehension among third-grade students". Journal of European Education, Volume 1 Issue 12011.

Campbell, L. dan Campbell, B. (2009). Mindful learning: 101 proven strategies for student and teacher success. CA: Corwin Press.

Covey. S.R. (2008). Seven Habits Of Highly Effective People. Ringkasan Padat diolah oleh Sumargi Raharjo. Cetak pdf oleh MGI /Personal-Enhanced Public Project.

Funke, J. (2013). "Human problem solving in 2012". Journal of Problem Solving, Volume 6, Issue 1, pages 2-19.

Hite, S. (2009). Improving problem solving by improving reading skills. Tesis pada Universitas Nebraska-Lincoln.

Imam, O.A., Abas-Mastura, M, Jamil, H. (2013). "Correlation between reading comprehension skills and students' performance in mathematics". International Journal of Evaluation and Research in Education (IJERE) Vol.2, No.1, March 2013, pp. 1 8 ISSN: 2252-8822.

Ismaimuza, D. (2011). "Kemampuan berpikir kritis matematis ditinjau dari pengetahuan awal siswa”. Jurnal Pendidikan Matematika, Volume 2 Nomor 1, Januari 2011.

Kenney, J.M. (2005). Literacy strategies for improving mathematics instruction. USA: ASCD.

Lally, P., van Jaarsveld, C.H.M., Potts, H.W.W., dan Wardle, J. (2010). "How are habits formed: Modelling habit formation in the real world". European Journal of Social Psychology, vol. 40, issue 6, pages 998-1009.

Lester, J.H. dan Head, M.H. (1999). Literacy and learning: reading in the content areas. Louisiana: Louisiana Public Broadcasting.

Lie, A. (2002). Cooperative learning: Mempraktikkan cooperative learning di ruang-ruang kelas. Jakarta: PT Grasindo. 
Morocco, C.C., Aguilar, C.M., dan Bershad, C.J. (2008). Supported literacy for adolescents: Transforming teaching and content learning for the twenty-first century. CA: Jossey-Bass.

Murray, J. (2013). "The Factors that Influence Mathematics Achievement at the Berbice Campus". International Journal of Business and Social Science, Vol. 4 No. 10 [Special Issue -August 2013].

Orhun, N. (2003). Effects of Some Properties 5. Grade Students on the Performance of Mathematical Problem Solving. The Mathematics Education into the $21^{\text {st }}$ Century Project Proceedings of the international Conference The Decidable and the Undecidable in Mathematics Education Brno, Czech Republic, September 2003.

Ozsoy, G., Kuruyer, H.G., dan Cakiroglu, A. (2015). "Evaluation of student's mathematical problem solving skills ini relation to their reading level". International Electronic Journal of Elementary Education, 8(1), 113-132.

Pearce, D.L., Bruun, F., Skinner, K., dan Lopez-Mohler, C. (2013). "What teachers say about student difficulties solving mathematical word problems in grades 2-5". International Electronic Journal of Mathematics Education, Vol.8, No.1.

Phonapichat, P., Wongwanich, S., dan Sujiva, S. (2014). "An analysis of elementary school students' difficulties in mathematical problem solving”. Procedia-Social and Behavioral Sciences, 116(2014), 3169-3174.

Raduan, I.H. (2010). "Error analysis and the corresponding cognitive activities committed by year five primary students in solving mathematical word problems". Procedia Social and Behavioral Sciences 2 (2010) 3836-3838.

Roschelle, J. (1995). Learning in Interactive Environments: Prior Knowledge and New Experience. (Online). Tersedia: http://www.exploratorium.edu/ifi-archive/resources/museumeducation/ priorknowledge.html. (10 Juli 2016).

Rose, K. (2011). The effect of SQRQCQ on fourth graders' math word problem performance. Tesis pada Bowling Green State University.

Sawyer, W.E. (2012). Growing up with literature. Edisi keenam. USA: Wadsworth.

Simanjuntak, L., dkk. (1992). Metode mengajar matematika I. Jakarta: Rineka Cipta.

Tankersley, K. (2005). Literacy strategies for grades 4-12: Reinforcing the threads of reading. USA: ASCD.

TeacherVision (tt). Mindful Learning: 101 Proven Strategies for Student and Teacher Success. (Online). Tersedia: https://www.teachervision.com. (17 Juli 2016)

Torner, Schoenfeld, \& Reiss (2007). "Problem solving in the mathematics classroom: the German perspective". ZDM Mathematics Education, (2007) 39:431-441. DOI 10.1007/s11858-0070040-5.

Vilenius-Tuohimma, P.M., Aunola, K., dan Nurmi, J. (2008). "The association between mathematical word problems and reading comprehension". Educational Psychology, Vol. 28, No. 4, July 2008, 409-426.

Wahyudin (2008). Pembelajaran dan model-model pembelajaran. Jakarta: CV. IPA Abong.

Wood, W. dan Neal, D.T. (2007). "A new look at habits and the habit-goal interface". Psychological Review, vol. 114, no. 4, 843- 863. 